\title{
Dynamic Compressive Property of Closed-Cell Mg Alloy Composite Foams Reinforced with SiC Particles
}

\author{
Wen-Zhan Huang ${ }^{1,2} \cdot$ Hong-Jie Luo ${ }^{1,2} \cdot$ Yong-Liang Mu ${ }^{1,2} \cdot$ Jian-Rong $\mathrm{Xu}^{1,2} \cdot \mathrm{Ai}^{-C h u n ~ Z h a o}{ }^{3}$
}

Received: 25 October 2018 / Revised: 15 December 2018 / Published online: 24 April 2019

(C) The Chinese Society for Metals (CSM) and Springer-Verlag GmbH Germany, part of Springer Nature 2019

\begin{abstract}
The high-strain-rate mechanical response of $\mathrm{Mg}$ alloy/ $\mathrm{SiC}_{\mathrm{p}}$ composite foams has received increased attention in recent years due to their light weight and potential to absorb large amounts of energy during deformation. Dynamic compressive properties of closed-cell $\mathrm{Mg}$ alloy $/ \mathrm{SiC}_{\mathrm{p}}$ composite foams with different relative densities $(0.162,0.227$ and 0.351$)$ and different $\mathrm{SiC}_{\mathrm{p}}$ additions (0, 4 and $8 \mathrm{wt} \%$ ) have been investigated using Split-Hopkinson pressure bar. It is shown that peak stress and energy absorption capacity significantly increase as the relative density increases at the range of testing strain rates. Peak stress and energy absorption display strain rate dependence. The peak stress of specimens with $0 \mathrm{wt} \%$ and $4 \mathrm{wt} \% \mathrm{SiC}$ particles additions grows with increasing strain rate. Meanwhile, the increment in the peak stress of specimens with 8 wt $\%$ addition is not significant with strain rate increasing. The increase in strain rate increases the energy absorption capacity. The suitable amount of $\mathrm{SiC}$ particles addition has great advantages over increasing the peak stress and energy absorption capacity at the high strain rate. The strain-rate-sensitive matrix, cell morphology, morphological defects and gas pressure have an impact on the strain-rate sensitivity of $\mathrm{Mg}$ alloy/SiC $\mathrm{p}$ composite foams.
\end{abstract}

Keywords $\mathrm{Mg}$ alloy $\cdot \mathrm{SiC}$ particles $\cdot \mathrm{Mg}$ alloy/SiC $\mathrm{p}$ composite foam $\cdot$ Split-Hopkinson pressure bar system (SHPB) . Dynamic compressive

\section{Introduction}

Foamed metallic materials have become potential materials for lightweight multifunctional applications due to their excellent physical and mechanical properties [1,2]. Because of the cellular structure, closed-cell metal foams exhibit an excellent damping capacity, an outstanding sound and noise isolation and a great energy absorption [3, 4]. In practical applications, metal foams are usually subjected to

Available online at http://link.springer.com/journal/40195

Hong-Jie Luo

neuhjluo@sina.com

1 School of Metallurgy, Northeastern University, Shenyang 110819, China

2 Engineering Research Center of Ministry of Education for Advanced Materials Preparation Technology, Shenyang 110819, China

3 School of Materials Science and Engineering, Taiyuan University of Science and Technology, Taiyuan 030024, China high-strain-rate compressive loads. Therefore, it is necessary to investigate the compressive behavior of metal foams under dynamic compression.

Among different kinds of metallic foams, majority of the works have been focused on $\mathrm{Al}$ foams and its alloy foams [5-13]. Many researchers have investigated the mechanical properties of $\mathrm{Al}$ foams under high strain rate impact loading, but there exist contradictory opinions. Compressive strength of some closed-cell $\mathrm{Al}$ foams is strain rate dependent over varying strain rates [5-9]. Alporas (manufactured by a melt route) has been reported to exhibit a strain-rate sensitivity $[8$, 9], and the particulate $\mathrm{SiC}_{\mathrm{p}} / \mathrm{Al}-\mathrm{Si}_{9} \mathrm{Mg}$ composite foam has been found to be more sensitive to strain rate than $\mathrm{Al}$ and $\mathrm{Al}$ alloy foams [10]. On the other hand, other researchers have showed that the compressive strength of $\mathrm{Al}$ foams is apparently insensitive to strain rate. Kenny [11] and Wang et al. [12] have found that the strain-rate dependence of plateau stress for open-cell $\mathrm{Al}$ foam is negligible. Moreover, alulight (manufactured by a powder route) is insensitive to strain rate [13]. This arises mainly because of their different foam structures (cell shapes and sizes), porosities, homogeneity of cell walls and defects in the cell walls and fabrication 
methods of foams. Previous studies have shown that the property of the cell wall material, the morphology of the cell and the preparation method might affect the high-strain-rate mechanical response of metal foams.

Recently, $\mathrm{Mg}$ and $\mathrm{Mg}$ alloy foams with the matrix density approximately two-thirds of aluminum show more promising for ultra-light metal structural materials and multifunctional materials [14]. A few recent investigations have been carried out on the compressive properties of $\mathrm{Mg}$ and $\mathrm{Mg}$ alloy foams [15-17] at low loading rates. However, there is a scarcity of studies focusing on the dynamic behavior of $\mathrm{Mg}$ alloy foams $[18,19]$. Limited work is found about the effect of relative densities and $\mathrm{SiC}$ particles on the dynamic mechanical behavior of closed-cell $\mathrm{Mg}$ alloy/SiC $\mathrm{p}$ composite foams. Therefore, further investigations are needed to examine the combined effects of strain rates, relative densities and $\mathrm{SiC}$ particles on the dynamic mechanical properties of $\mathrm{Mg}$ alloy/ $\mathrm{SiC}_{\mathrm{p}}$ composite foams, i.e., peak stress and energy absorption capacity.

The aim of the study reported here is to investigate the strain rate sensitivities of $\mathrm{Mg}$ alloy/SiC $\mathrm{p}$ composite foams and the effects of relative densities and mass fraction of $\mathrm{SiC}$ particle on the dynamic compressive property. To achieve this goal, closed-cell $\mathrm{Mg}$ alloy/SiC $\mathrm{p}_{\mathrm{p}}$ composite foams with uniform cell distribution and small size diameter were fabricated using $\mathrm{MgCO}_{3}$ as the foaming agent and $\mathrm{SiC}_{\mathrm{p}}$ as the stabilizing agent. The Split-Hopkinson pressure bar (SHPB) technique was applied to measure the dynamic compressive behavior. After evaluation on the dynamic compressive behavior, mechanisms for the effects are discussed to be beneficial to the applications of $\mathrm{Mg}$ alloy/SiC $\mathrm{p}$ composite foams.

\section{Experimental}

\subsection{Materials and Specimens}

Closed-cell $\mathrm{Mg}$ alloy/SiC $\mathrm{p}$ composite foams were fabricated by the melt foaming process. After $\mathrm{Mg}-\mathrm{Al}-\mathrm{Ca}$ alloy (12 wt \% $\mathrm{Al}, 3 \mathrm{wt} \% \mathrm{Ca})$ was melted, the $\mathrm{SiC}_{\mathrm{p}}$ stabilizing agent $(80 \mu \mathrm{m})$ was added into the melt at $580{ }^{\circ} \mathrm{C}$, with a stirring rate of $2000 \mathrm{rpm}$ for $300 \mathrm{~s}$. Then, the $\mathrm{MgCO}_{3}(100 \mu \mathrm{m})$ foaming agent mixed with $\mathrm{Al}_{2} \mathrm{O}_{3}$ particles $(100 \mu \mathrm{m})$ at a mass ratio of $1: 1$, as an assistant dispersive agent, was added into the melt together at $580{ }^{\circ} \mathrm{C}$, at the stirring rate of $1500 \mathrm{rpm}$ for a certain time limit. The melt was put in a furnace at $620^{\circ} \mathrm{C}$ for $180 \mathrm{~s}$. The $\mathrm{Mg}$ alloy/SiC $\mathrm{p}_{\mathrm{p}}$ composite foams were obtained after the melt was taken out and cooled to room temperature. When using different fabrication parameters, such as the foaming agent content and stirring time for adding the foaming agent, the $\mathrm{Mg}$ alloy/ $\mathrm{SiC}_{\mathrm{p}}$ composite foams with density in a range of $0.20-0.78 \mathrm{~g} / \mathrm{cm}^{3}$ were generated.
The effect of fabrication parameters on preparation of the composite foams has been discussed in another paper [20].

\subsection{Structure Characterization}

The composite foams were cut into $\varnothing 10 \mathrm{~mm} \times 8 \mathrm{~mm}$ by an electric discharge machining method. The specimen's density was determined through its mass and physical dimensions. Its relative density (RD) is defined as the value which is the density of composite foams divided by the density of $\mathrm{Mg}$ alloy matrix. The equation is given as follows:

$\mathrm{RD}=\frac{\rho}{\rho_{\mathrm{s}}}$,

where $\rho$ and $\rho_{\mathrm{s}}$ are the densities of the composite foams and the cell wall material, respectively.

The average diameter of cells was measured based on counting 600 cells according to Image-Pro Plus software. The microstructural features in composite foam were observed by scanning electron microscopy (SEM) on a microscope (Ultra Plus, Zeiss, Germany) equipped with an energy-dispersive X-ray spectroscopy (EDS) apparatus (X-Max, Oxford Instruments, England).

\subsection{Mechanical Testing}

Cylindrical specimens of the diameter $D=10 \mathrm{~mm}$ and length $\mathrm{l}=8 \mathrm{~mm}$ were machined from the $\mathrm{Mg}$ alloy $/ \mathrm{SiC}_{\mathrm{p}}$ composite foam for high-strain-rate compression tests. All the specimens were lubricated to further minimize the interfacial friction. High-strain-rate compression tests were performed on Split-Hopkinson pressure bar system (SHPB) at strain rates ranging from 700 to $2500 \mathrm{~s}^{-1}$.

The SHPB is made of solid cylindrical aluminum bars with the diameter of $12.5 \mathrm{~mm}$. The lengths of striker, incident and transmitted bars are $200 \mathrm{~mm}, 900 \mathrm{~mm}$ and $900 \mathrm{~mm}$, respectively. A schematic graph of the typical SHPB system can be found in Refs. [21, 22]. The specimen is sandwiched between the end of incident bar and the front of transmitted bar. The strain gauges mounted at the bars measure the strain waves in these bars, from which the resisting force and deformation rate of the specimen can be calculated under the assumption of uniaxial elastic stress wave propagation [19, 21-24].

\section{Results and Discussion}

\subsection{Morphology Observation}

Figure 1 shows the macrostructure and microstructure of closed-cell $\mathrm{Mg}$ alloy/SiC $\mathrm{S}_{\mathrm{p}}$ composite foams with $4 \mathrm{wt} \% \mathrm{SiC}_{\mathrm{p}}$ 

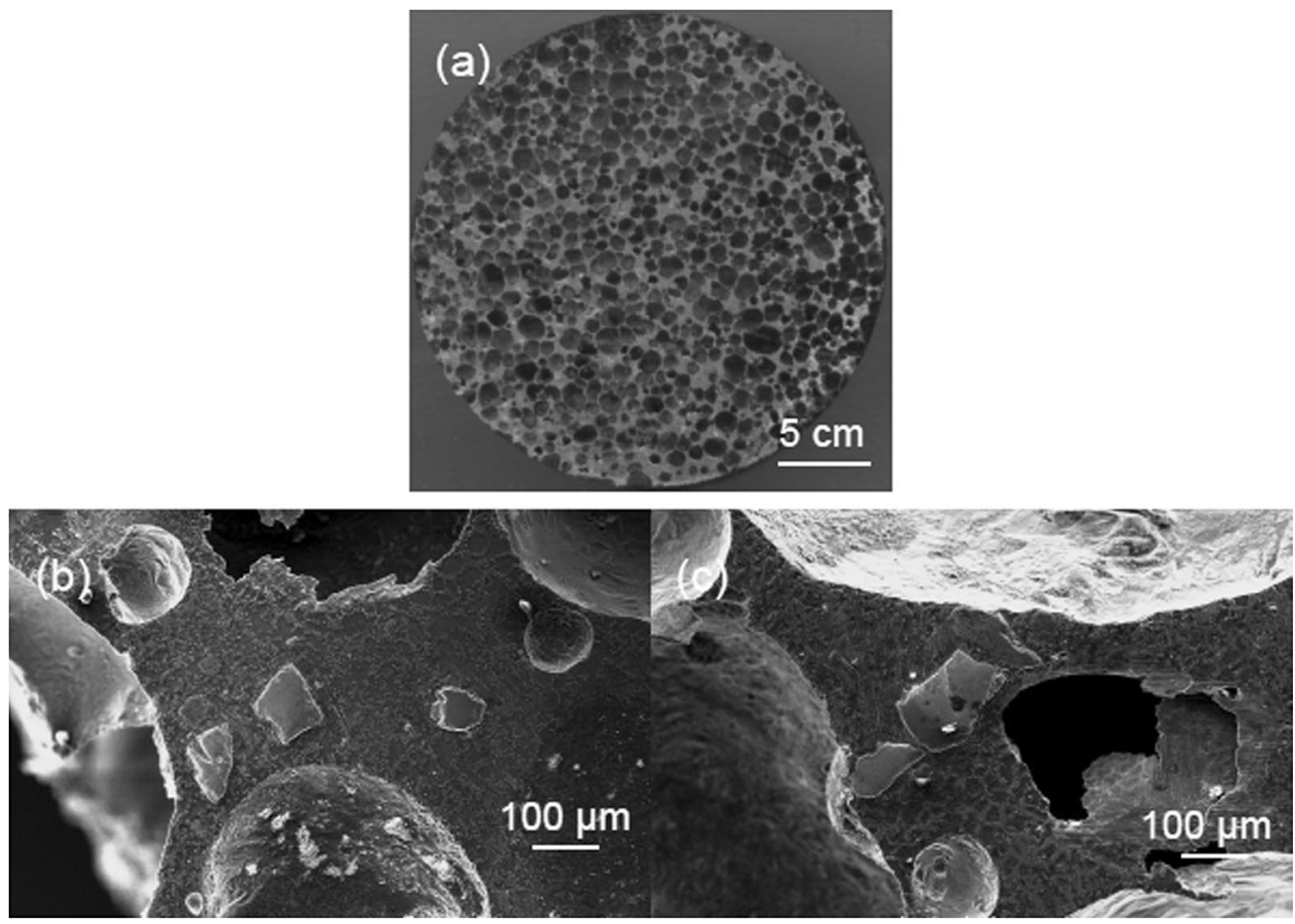

Fig. 1 Macrostructure and microstructure of closed-cell $\mathrm{Mg}$ alloy/ $\mathrm{SiC}_{\mathrm{p}}$ composite foams with $4 \mathrm{wt} \% \mathrm{SiC}$ : a the present closed-cell foam with a relative density of $0.227, \mathbf{b}, \mathbf{c}$ distribution of $\mathrm{SiC}_{\mathrm{p}}$ in the cell wall of foams

addition. A typical foam structure is shown in Fig. 1a. Note that the density was controlled by the processing parameters during the direct foaming process. The average diameter of cells was measured to be $\sim 0.8 \mathrm{~mm}$ according to the ImagePro Plus software. As shown in Fig. 1b, c, the uniform distribution and non-agglomeration of $\mathrm{SiC}$ particle in the cell wall indicate the good wettability at the $\mathrm{SiC}_{\mathrm{p}}-\mathrm{Mg}$ alloy melt interface, and the interface is distinct. Furthermore, heterogeneities and morphological defects such as uneven cell-wall thickness and fractured/missing cell walls are observed in the cell structure.

\subsection{Effect of Relative Densities on Dynamic Compressive Response}

Figure $2 \mathrm{a}-\mathrm{c}$ shows engineering stress-strain plots under dynamic compression at different strain rates and relative densities. It is observed that compressive stresses at any fixed relative density increase with the strain rate. The $\mathrm{Mg}$ alloy/SiC $\mathrm{S}_{\mathrm{p}}$ composite foams with different relative densities $(\mathrm{RD}=0.162,0.227$ and 0.351$)$ exhibit an increase in peak stresses with strain rate up to $2500 \mathrm{~s}^{-1}$. A critical strain rate is not observed. The critical strain rate means that the peak stress does not gain beyond this strain rate. Overall, higher increment in peak stress is observed for higher relative densities as the strain rate increases.
This shows an agreement with the reported results of the Al alloy foam [22], which is a higher density foam that exhibits a significant increase in compressive stress under dynamic compression.

In this study, peak stress $\left(\sigma_{\text {Peak }}\right)$ is also termed as the elastic collapse stress $\left(\sigma_{\mathrm{el}}\right)$. Figure 3 shows the variation of peak stress as a function of strain rates at different relative densities. When the strain rates are $800 \mathrm{~s}^{-1}, 800 \mathrm{~s}^{-1}$ and $700 \mathrm{~s}^{-1}$, it is found that the peak stress of specimens is around 5.7, 12.1 and 28.3 MPa corresponding to the relative densities of $0.162,0.227$ and 0.351 , respectively. Meanwhile, the peak stress of specimens is around 9.3,19.9 and $48.7 \mathrm{MPa}$ when the strain rates are $2500 \mathrm{~s}^{-1}, 2500 \mathrm{~s}^{-1}$ and $2100 \mathrm{~s}^{-1}$, respectively. It is noted that peak stress of specimen with relative density of 0.351 increases the most. The peak stress of specimen with relative density of 0.351 is enhanced by $20.4 \mathrm{MPa}$ as the strain rate increases from 700 to $2100 \mathrm{~s}^{-1}$. This may be attributable to the additional effect of the gas pressure in the closed cell as described in other studies [10, 21]. In the lower-density $\mathrm{Mg}$ alloy/SiC $\mathrm{S}_{\mathrm{p}}$ composite foam specimens, more cell walls are thin and easy to be "blown out" at higher strain levels, which allow the gas to escape. As densities of $\mathrm{Mg}$ alloy/SiC $\mathrm{p}$ composite foam specimens increase, the cell walls become stout and restrict the escape of gas. Thus, the gas pressure may contribute more to the strain-rate sensitivity of high relative density $\mathrm{Mg}$ alloy/SiC 


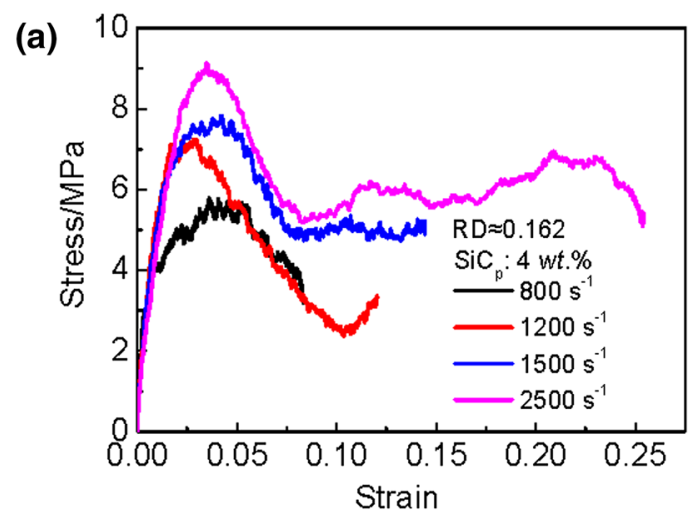

(b)

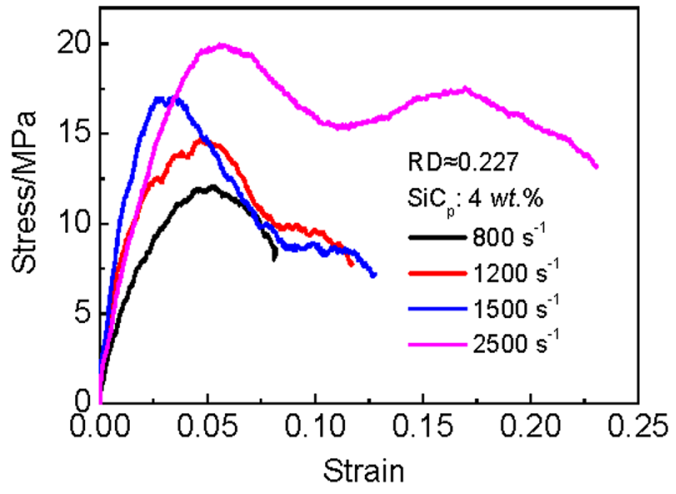

(c)

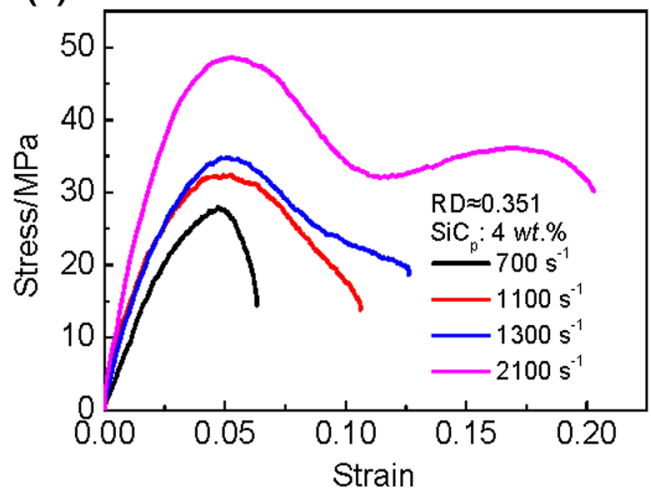

Fig. 2 Dynamic compressive stress-strain response of $\mathrm{Mg}$ alloy/ $\mathrm{SiC}_{\mathrm{p}}$ composite foam with different relative densities: a 0.162 , b 0.227 , c 0.351

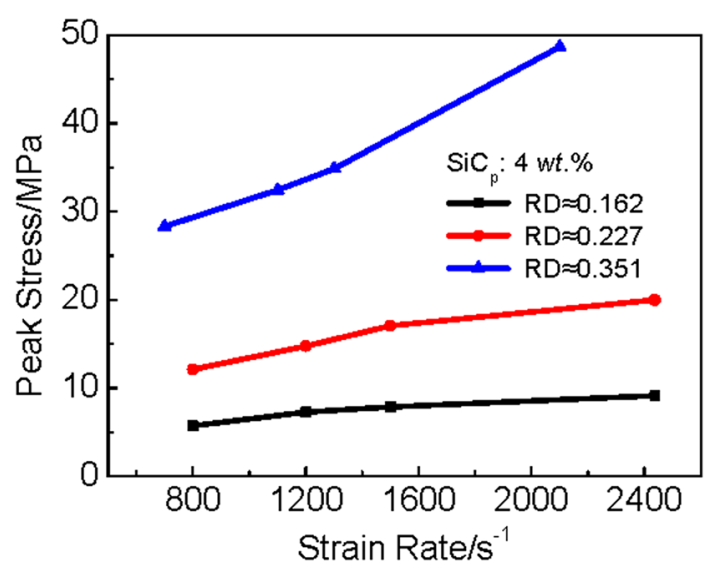

Fig. 3 Peak stress against strain rates at different relative densities

composite foams than that of low relative density Mg alloy/ $\mathrm{SiC}_{\mathrm{p}}$ composite foams.

Wang et al. [5] investigated the dynamic behaviors of aluminum foam subjected to impacting loading at temperatures ranging from 298 to $773 \mathrm{k}$. The results illustrated that strain rate effect at elevated temperature was more sensitive than that at room temperature. The deformation of aluminum foam under dynamic loading mainly resulted from the plastic bending of the cell wall at elevated temperatures, but there existed more buckling, tearing and debris profiles at room temperatures. The deformation of $\mathrm{Mg}$ alloy/SiC $\mathrm{p}_{\mathrm{p}}$ composite foams in this study under dynamic loading is similar to that of $\mathrm{Al}$ foam at room temperatures. Dannemann et al. [6] tested the dynamic compression behavior of Alporas (a closed-cell aluminum) at strain rate ranging from 400 to $2500 \mathrm{~s}^{-1}$. A strain rate effect was verified for Alporas. The strain-rate effect is attributed to gas pressure and the kinetics of gas flow through the cell structure and was more significant for a high-density Alporas foam, which is consistent with the results of this paper. Zhao et al. [7] studied the impact response of $\mathrm{Al}$ foams made from two different manufacturing processes (IFAM and Cymat) at speed of $10 \mathrm{~m} / \mathrm{s}$. For the IFAM aluminum foam, a rate sensitivity has been observed and the deforming mode is successive folding; for the Cymat foam, no rate sensitivity is observed and the deforming mode is cell wall fracture, which provides support for the fact that the micro-inertial effect in the successive folding process is an important factor for the rate sensitivity of $\mathrm{Al}$ foam. However, Deshpande and Fleck [13] consider that the micro-inertial effect plays little role in enhancing the strength of metallic foam due to the bending deformation mode attributed to the large number of imperfections in 
metallic foam. Meanwhile, $\mathrm{The} \mathrm{Mg}$ alloy/SiC $\mathrm{p}_{\mathrm{p}}$ composite foams is brittle. The deformation under dynamic loading mainly results from buckling, tearing and debris profiles of cell wall. Therefore, the micro-inertia effect thus has a negligible effect on the rate sensitivity of $\mathrm{Mg}$ alloy/SiC $\mathrm{p}_{\mathrm{p}}$ composite foams.

In the compressive test, the needed energy of any foam specimen up to the specific strain is defined as the energy absorption capacity [22]. Under compressive tests, energy absorption $(E)$ is given as the area under stress-strain curve from 0 to a specific strain $\varepsilon_{i}$ and calculated by the following expression:

$E=\int_{0}^{\varepsilon_{i}} \sigma(\varepsilon) \mathrm{d} \varepsilon$,

where $\sigma(\varepsilon)$ is the stress under the strain $\varepsilon$ and $\varepsilon_{i}$ is the selected strain. According to Eq. 2, energy absorption capacity of $\mathrm{Mg}$ alloy/SiC $\mathrm{p}_{\mathrm{p}}$ composite foams has been evaluated for different strain rates and relative densities. Figure 4 shows the energy absorption capacity of $\mathrm{Mg}$ alloy/SiC $\mathrm{p}_{\mathrm{p}}$ composite foams at the strain of $8 \%$ with strain rate ranging from 700 to $2500 \mathrm{~s}^{-1}$ for different relative densities. It can be found that the energy absorption capacity is strongly influenced by strain rate. When the strain rate is ranging from 700 to $2500 \mathrm{~s}^{-1}$, the increment in the energy absorption capacity is higher as the relative density increases. At the testing strain rate range, the energy absorption capacity of specimen with relative density of 0.351 increases the most as the strain rate increases. For the specimen with relative density of 0.351 , the energy absorption capacity increases from $1.21 \mathrm{MJ} / \mathrm{m}^{3}$ at a strain rate of $700 \mathrm{~s}^{-1}$ to $3.08 \mathrm{MJ} / \mathrm{m}^{3}$ at $2100 \mathrm{~s}^{-1}$.

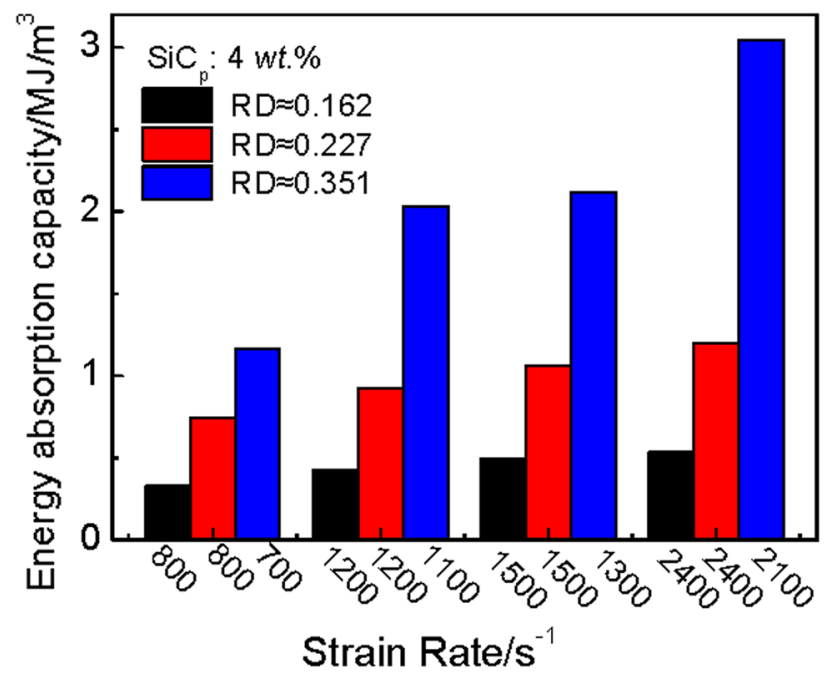

Fig. 4 Energy absorption capacity of $\mathrm{Mg}$ alloy/SiC $\mathrm{S}_{\mathrm{p}}$ composite foams versus strain rates with the relative densities of $0.162,0.227$ and 0.351 , respectively

\subsection{Effect of $\mathrm{SiC}_{\mathrm{p}}$ on Dynamic Compressive Response}

The effect of the different $\mathrm{SiC}$ particles additions on dynamic mechanical property of $\mathrm{Mg}$ alloy/SiC $\mathrm{p}$ composite foams with the relative density of $\sim 0.18$ in the strain rate range $800-2500 \mathrm{~s}^{-1}$ is shown in Fig. 5. In Fig. 5a, b, the peak stress increases with the increase in strain rate. The peak stress is sensitive to the strain rate when the $\mathrm{SiC}$ particles addition is $0 \mathrm{wt} \%$ and $4 \mathrm{wt} \%$. Compared with specimens with $0 \mathrm{wt} \%$ $\mathrm{SiC}$ particles addition, specimens with $4 \mathrm{wt} \% \mathrm{SiC}$ particles addition have apparent high peak stress at the same strain rate. It proves that suitable amount of $\mathrm{SiC}$ particle addition has great advantages for increasing the peak stress at the high strain rate. It can be interpreted that the peak stress of $\mathrm{Mg}$ matrix alloy composites reinforced by $\mathrm{SiC}$ particle is higher than that of Mg matrix alloy due to the strengthening effect of $\mathrm{SiC}$ particles. It has been discussed in detail in another article [25]. Meanwhile, the additional effect of the gas pressure in the closed cell $[10,21]$ of the specimens with $4 \mathrm{wt} \% \mathrm{SiC}$ particles addition plays a greater role than that of the specimens with $0 \mathrm{wt} \% \mathrm{SiC}$ particles addition. The cell wall with $4 \mathrm{wt} \% \mathrm{SiC}$ particles addition is hard to be "blown out." On the contrary, it is worth noting that the peak stress does not show a significant increasing trend with strain rate increasing in Fig. 5c. The peak stress of specimens with $8 \mathrm{wt} \% \mathrm{SiC}$ particles is insensitive to the strain rate. For the limited thickness of cell wall, increasing $\mathrm{SiC}_{\mathrm{p}}$ content has a limited strengthening effect. On the contrary, the greater the mass fraction of $\mathrm{SiC}$ particles is, the more brittle the composite foams are. In $\mathrm{Mg}$ alloy/ $\mathrm{SiC}_{\mathrm{p}}$ composite foam specimens with $8 \mathrm{wt} \% \mathrm{SiC}_{\mathrm{p}}$ addition, more cells are too brittle and easy to be "blown out" at higher strain levels. It allows the gas to escape and weakens the additional effect of the gas pressure in the closed cell. Thus, the increment in the peak stress of specimens with $8 \mathrm{wt} \% \mathrm{SiC}_{\mathrm{p}}$ addition is not evident with increasing strain rate.

It is shown that the peak stress of specimens with different $\mathrm{SiC}_{\mathrm{p}}$ additions changes with the strain rate increasing in Fig. 6. It is worth noting that peak stress of specimens with $0 \mathrm{wt} \%$ and $4 \mathrm{wt} \% \mathrm{SiC}_{\mathrm{p}}$ additions increases with the increase in strain rate; the peak stress of specimens with $8 \mathrm{wt} \% \mathrm{SiC}_{\mathrm{p}}$ addition does not show a significant increasing trend with increasing strain rate. The peak stress of specimens with $0 \mathrm{wt} \%, 4 \mathrm{wt} \%$ and $8 \mathrm{wt} \% \mathrm{SiC}_{\mathrm{p}}$ additions is enhanced by $2.94 \mathrm{MPa}, 5.19 \mathrm{MPa}$ and $0.63 \mathrm{MPa}$ as the strain rate increased from 800 to $2500 \mathrm{~s}^{-1}$. The increment in specimens with $0 \mathrm{wt} \%$ and $4 \mathrm{wt} \% \mathrm{SiC}$ particles additions is an order of magnitude higher than that of specimens with $8 \mathrm{wt} \% \mathrm{SiC}_{\mathrm{p}}$ addition. It is obvious that the increment in the peak stress of specimens with $4 \mathrm{wt} \% \mathrm{SiC}$ particles addition is higher than that of specimens with $0 \mathrm{wt} \% \mathrm{SiC}$ particles addition with strain rate increasing. It can be predicted that 

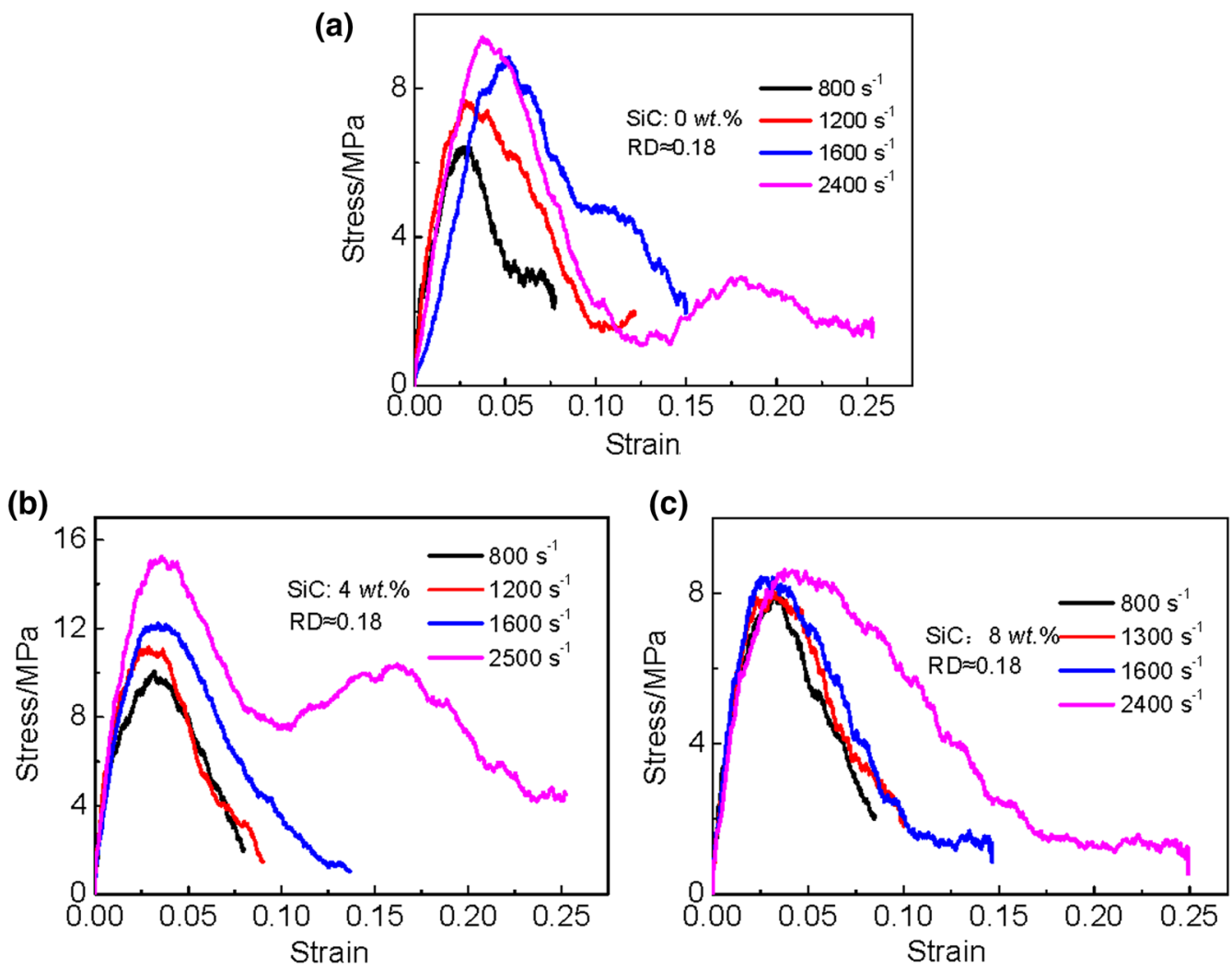

Fig. 5 Dynamic compressive stress-strain response of $\mathrm{Mg}$ alloy/SiC $\mathrm{S}_{\mathrm{p}}$ composite foam with different $\mathrm{SiC}_{\mathrm{p}}$ additions: a $0 \mathrm{wt} \%$, b $4 \mathrm{wt} \%$, c $8 \mathrm{wt} \%$

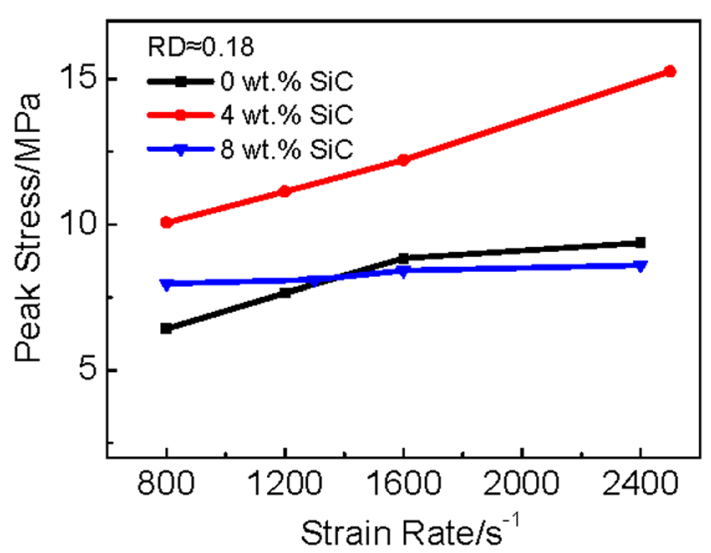

Fig. 6 Variation in the peak stress of specimens with different $\mathrm{SiC}_{\mathrm{p}}$ additions with increasing strain rates

suitable $\mathrm{SiC}_{\mathrm{p}}$ addition in the $\mathrm{Mg}$ alloy/SiC $\mathrm{p}$ composite foams increases the strain rate sensitivity of specimens.

Yu et al. [10] studied the dynamic compressive behaviors of $\mathrm{SiC}_{\mathrm{p}} / \mathrm{AlSi}_{9} \mathrm{Mg}$ composite foams at the strain rate ranging from 600 to $1600 \mathrm{~s}^{-1}$. The experimental results showed that $\mathrm{SiC}_{\mathrm{p}} / \mathrm{AlSi}_{9} \mathrm{Mg}$ composite foams had a strain rate effect and was more sensitive to the strain rate than $\mathrm{Al}$ and $\mathrm{Al}$ alloy foams. The yield stress of the composite foams with different
$\mathrm{SiC}$ particles addition at high strain rate increased with the increase in the volume fraction of $\mathrm{SiC}$ particles. $\mathrm{SiC}_{\mathrm{p}}$ particles played a strengthening effect in $\mathrm{SiC}_{\mathrm{p}} / \mathrm{AlSi}_{9} \mathrm{Mg}$ composite foams. Meanwhile, $\mathrm{SiC}_{\mathrm{p}}$ particles made the composite foams more brittle because the addition of $\mathrm{SiC}$ particles leads to more interface. The mechanism of $\mathrm{SiC}$ particles in dynamic compression process of $\mathrm{SiC}_{\mathrm{p}} / \mathrm{AlSi}_{9} \mathrm{Mg}$ composite foams is the same as that of $\mathrm{Mg}$ alloy/SiC $\mathrm{p}$ composite foams. However, the peak stress of specimens with $8 \mathrm{wt} \% \mathrm{SiC}$ particles is insensitive to the strain rate in this study, which is not observed in the other studies [10,25]. This may be caused by that the ceramic particle content in the other studies still does not exceed the critical value.

Figure 7 shows the energy absorption capacity of $\mathrm{Mg}$ alloy/SiC $\mathrm{p}_{\mathrm{p}}$ composite foams with different $\mathrm{SiC}_{\mathrm{p}}$ additions at the strain of $8 \%$ with strain rate ranging from 800 to $2500 \mathrm{~s}^{-1}$. It can be found that the energy absorption capacity increases with strain rate increasing. When the strain rate is ranging from 800 to $2500 \mathrm{~s}^{-1}$, the increment in the energy absorption capacity of specimens is $0.215,0.382$ and $0.131 \mathrm{MJ} / \mathrm{m}^{3}$ corresponding to the $\mathrm{SiC}_{\mathrm{p}}$ addition of 0,4 and $8 \mathrm{wt} \%$. At the testing strain rate range, the energy absorption capacity of specimen with $4 \mathrm{wt} \% \mathrm{SiC}_{\mathrm{p}}$ addition grows the most as the strain rate increases. Compared with the specimens with different relative densities, the increment in the 


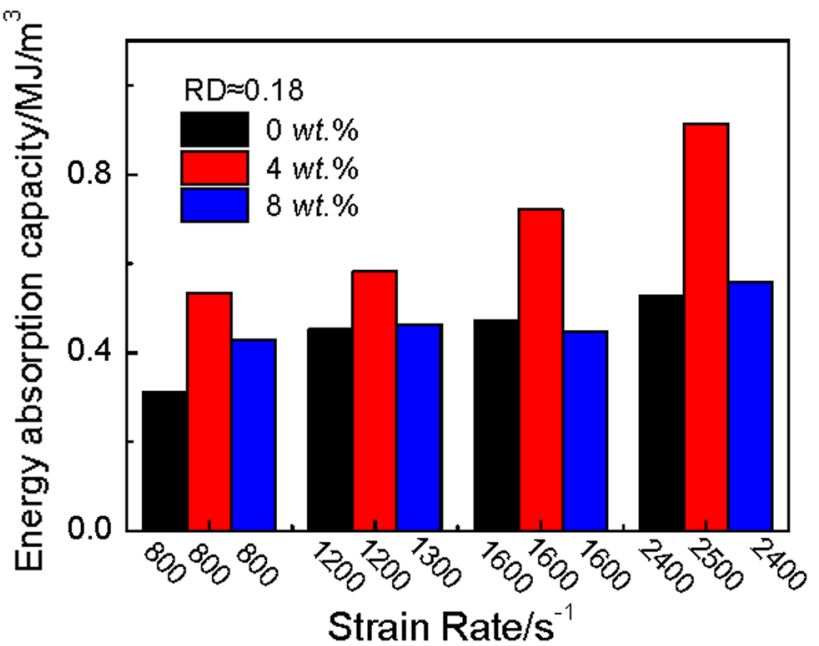

Fig. 7 Energy absorption capacity of $\mathrm{Mg}$ alloy/ $\mathrm{SiC}_{\mathrm{p}}$ composite foams versus strain rates with different $\mathrm{SiC}_{\mathrm{p}}$ additions

energy absorption capacity of the specimens with different $\mathrm{SiC}_{\mathrm{p}}$ additions is small.

Figure 8 shows the compressive final morphologies of $\mathrm{Mg}$ alloy/ $\mathrm{SiC}_{\mathrm{p}}$ composite foams with $8 \mathrm{wt} \% \mathrm{SiC}_{\mathrm{p}}$ with strain rate ranging from 800 to $2400 \mathrm{~s}^{-1}$. The composite foams produce many crushed fragments at strain rate of $2400 \mathrm{~s}^{-1}$. When the strain rate increases from 800 to $2400 \mathrm{~s}^{-1}$, more and more fragments are observed, which indicates that the composite foams display brittle fracture behavior. The brittleness of the $\mathrm{Mg}$ alloy/SiC $\mathrm{S}_{\mathrm{p}}$ composite foams induces the stress oscillations during compression, which is in agreement with the observations in Figs. 2 and 5.

Figure 9 demonstrates the SEM image of the fracture surfaces in the fragments of the $\mathrm{Mg}$ alloy/SiC $\mathrm{p}$ composite foams after the dynamic compression. The cracks in the weak link and defects in the cells are shown in Fig. 9a. Meanwhile, cracks occur at multiple locations along the cell wall resulting in the fracture and collapse of the cell wall. It is shown that fracture and collapse occur on the cell wall resulting in producing crushed fragments in Fig. 9b, which is in agreement with the observations in Fig. 8. In addition, the cell edge is more prone to fracture and collapse (shown from Fig. 9c, d) than the plateau border. The fracture and collapse occur along the cell edge, while plateau border is still relatively intact.

\subsection{Mechanisms of the Strain-Rate Sensitivity of $\mathbf{M g}$ Alloy Foam}

The exact mechanisms of the strain-rate sensitivity of $\mathrm{Mg}$ alloy/ $\mathrm{SiC}_{\mathrm{p}}$ composite foam have not been established. The most prevalent explanation is that metal foam with a ratesensitive matrix is strain rate sensitive [26]. In addition, cell morphology and morphological defects also play a crucial rule in the rate sensitivity of metal foam $[8,19,26]$. The strain rate dependence of mechanical strength for $\mathrm{Mg}$ and $\mathrm{Mg}$ alloys has been demonstrated [27-29]. Thus, the strainrate-sensitive matrix contributes to the increase in the peak stress of $\mathrm{Mg}$ alloy/ $\mathrm{SiC}_{\mathrm{p}}$ composite foams at high strain rates. For the closed-cell $\mathrm{Mg}$ alloy/SiC $\mathrm{p}_{\mathrm{p}}$ composite foam, pressurization of the gas within the cells and movement of the gas through the cells as cell walls rupture, i.e., the gas pressure effect, also lead to strain rate dependency of $\mathrm{Mg}$ alloy/SiC composite foam. Morphological defects such as microcracks and mutilated cells are inevitable in the specimen as well. The defects allow the gas to escape. As discussed previously, it is clear that the strain-rate sensitivity of $\mathrm{Mg}$ alloy/SiC composite foam also can be attributed to the strain-rate-sensitive matrix. Moreover, cell morphology and morphological defects also play a crucial rule in the strain rate sensitivity of $\mathrm{Mg}$ alloy/ $\mathrm{SiC}_{\mathrm{p}}$ composite foam. Based on the discussions above, the stress of $\mathrm{Mg}$ alloy/ $\mathrm{SiC}_{\mathrm{p}}$ composite foam at high strain rates is mainly composed of three parts. An equation on stress at high strain rates is given by

$\sigma=\sigma_{\mathrm{Mg}}+\sigma_{\mathrm{CS}}+\sigma_{\mathrm{GP}}$,

where $\sigma$ is the stress of $\mathrm{Mg}$ alloy/SiC $\mathrm{p}_{\mathrm{p}}$ composite foam at high strain rates, $\sigma_{\mathrm{Mg}}$ is the stress influenced by the $\mathrm{Mg}$ alloy/ $\mathrm{SiC}_{\mathrm{p}}$ matrix, $\sigma_{\mathrm{CS}}$ is the stress affected by cell structure and $\sigma_{\mathrm{GP}}$ is the stress impacted by the gas pressure. The major

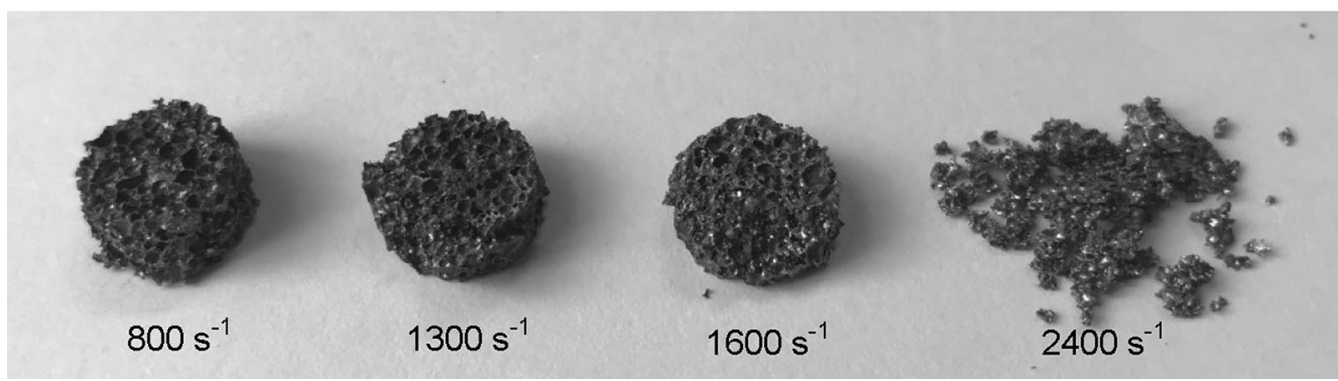

Fig. 8 Dynamic compressive final morphologies of $\mathrm{Mg}$ alloy/SiC $\mathrm{p}_{\mathrm{p}}$ composite foams with $8 \mathrm{wt} \% \mathrm{SiC}_{\mathrm{p}}$ with different strain rates 

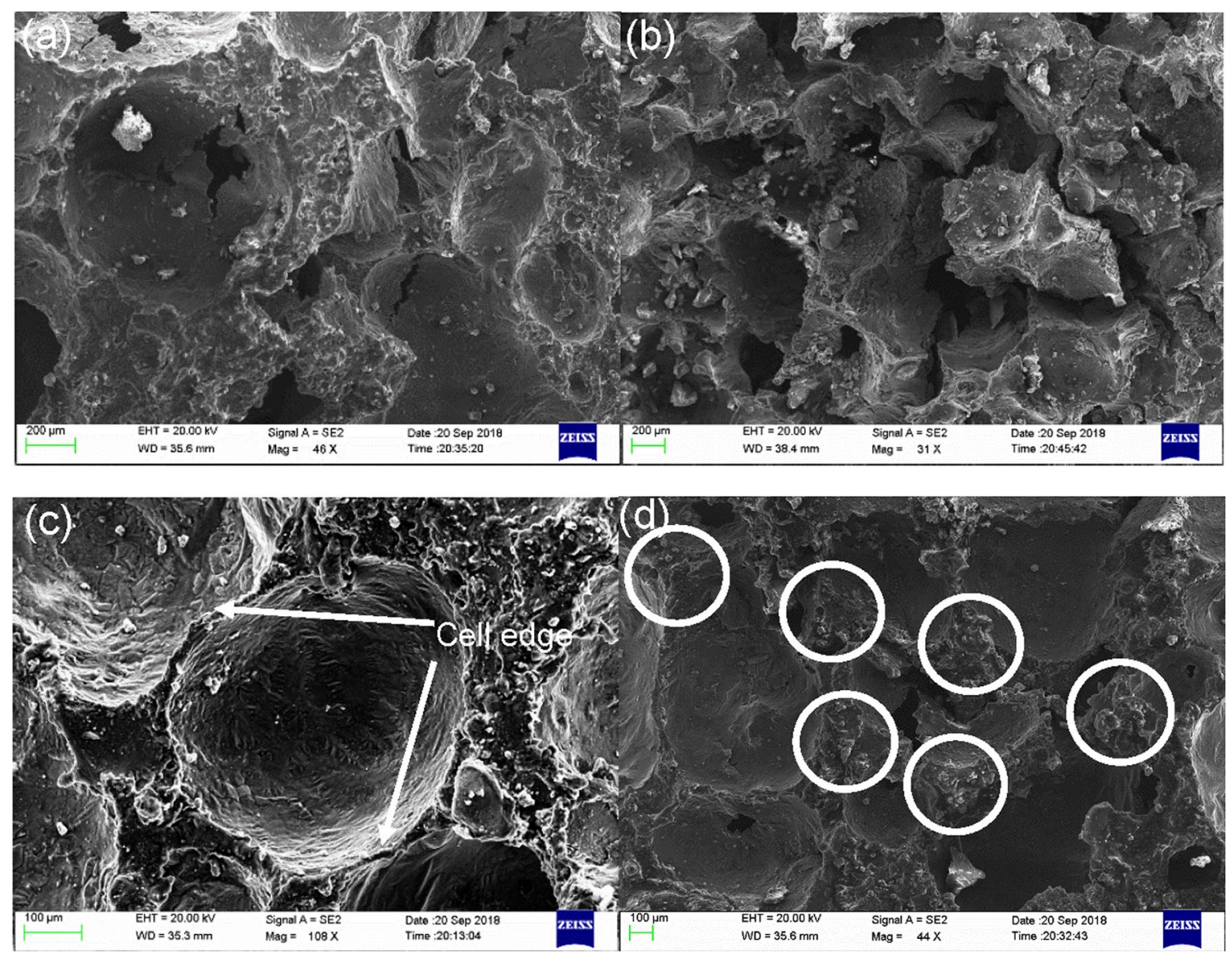

Fig. $9 \mathrm{SEM}$ image of the fracture surfaces in the fragments of the $\mathrm{Mg}$ alloy/SiC $\mathrm{p}_{\mathrm{p}}$ composite foams after the dynamic compression: a cracks in the cell walls, b-d the fracture and collapse of the cell wall. (Note: arrows indicate the cell edge, the boxed-in area of the figure (d) is plateau border)

effect among them is different at variation of high strain rates, relative densities and $\mathrm{SiC}_{\mathrm{p}}$ addition.

\section{Conclusions}

Dynamic compressive mechanical properties of closed-cell $\mathrm{Mg}$ alloy/SiC $\mathrm{p}$ composite foams have been investigated under dynamic loading with different relative densities $(0.162,0.227$ and 0.351$)$ and different $\mathrm{SiC}_{\mathrm{p}}$ additions $(0,4$ and $8 \mathrm{wt} \%$ ). Split-Hopkinson pressure bar was used to study the dynamic compression behavior. The conclusions were drawn as follows.

1. For similar strain rates, peak stress and energy absorption capacity are higher for higher relative densities. Specimen with relative density of 0.351 has the highest peak stress and energy absorption capacity.

2. For all densities, the peak stress and energy absorption capacity increase with the strain rate. Peak stress and energy absorption display strain rate dependence. At the testing strain rate ranges, the higher the relative densities are, the higher the increment in peak stress and energy absorption capacity will be, when the strain rate increases. Both peak stress and energy absorption capacity of specimen with relative density of 0.351 increase the most as the strain rate increases.

3. The peak stress of specimens with $0 \mathrm{wt} \%$ and $4 \mathrm{wt} \% \mathrm{SiC}$ particles additions increases with strain rate increasing. Meanwhile, the increment in the peak stress of specimens with $8 \mathrm{wt} \%$ addition is not evident with increasing strain rate. The energy absorption capacity increases with strain rate increasing. At the testing strain rate ranges, the increment in the energy absorption capacity of specimen with $4 \mathrm{wt} \% \mathrm{SiC}_{\mathrm{p}}$ addition is the most as the strain rate increases. The suitable amount of $\mathrm{SiC}$ particles addition has a great advantage for increasing the peak stress and energy absorption capacity at the high strain rate. 
Acknowledgements This work was financially supported by National Natural Science Foundation of China (Nos. 51874093, 51174060 and 51301109) and Fundamental Research Funds for the Central Universities (No. N162410002-2-10).

\section{References}

[1] L.J. Gibson, M.F. Ashby, Cellular Solids: Structures and Properties (Cambridge University Press, Cambridge, 1997)

[2] H. Kanahashi, T. Mukai, Y. Yamada, K. Shimojima, M. Mabuchi, T. Aizawa, K. Higashi, Mater. Sci. Eng. A 308, 283 (2001)

[3] X.H. Liu, H.Y. Huang, J.X. Xie, Int. J. Min. Met. Mater. 21, 687 (2014)

[4] D.R. Tian, Y.H. Pang, L. Yu, L. Sun, Int. J. Min. Met. Mater. 23, 793 (2016)

[5] P.F. Wang, S.L. Xu, Z.B. Li, J.L. Yang, H. Zheng, S.S. Hu, Mater. Sci. Eng. A 599, 174 (2014)

[6] K.A. Dannemann, J. Lankford, Mater. Sci. Eng. A 29, 157 (2000)

[7] H. Zhao, I. Elnasri, S. Abdennadher, Int. J. Mech. Sci. 47, 757 (2005)

[8] T. Mukai, H. Kanahashi, T. Miyoshi, M. Mabuchi, T.G. Nieh, K. Higashi, Scr. Mater. 40, 921 (1999)

[9] S. Ramachandra, P. Sudheer Kumar, U. Ramamurty, Scr. Mater. 49, 741 (2003)

[10] S.R. Yu, Y.R. Luo, J.A. Liu, Mater. Sci. Eng. A 487, 394 (2008)

[11] L.D. Kenny, Mater. Sci. Forum 217, 1883 (1996)

[12] Z.H. Wang, H.W. Ma, L.M. Zhao, G.T. Yang, Scr. Mater. 54, 83 (2006)
[13] V.S. Deshpande, N.A. Fleck, Int. J. Impact Eng. 24, 277 (2000)

[14] W.Z. Huang, H.J. Luo, Y.L. Mu, H. Lin, H. Du, Int. J. Min. Met. Mater. 24, 701 (2017)

[15] D.H. Yang, S.R. Yang, H. Wang, A.B. Ma, J.H. Jiang, J.Q. Chen, D.L. Wang, Mater. Sci. Eng. A 527, 5405 (2010)

[16] Z.G. Xu, J.W. Fu, T.J. Luo, Y.S. Yang, Mater. Des. 34, 40 (2012)

[17] Y. Yamada, K. Shimojima, Y. Sakaguchi, M. Mabuchi, M. Nakamura, T. Asahina, T. Mukai, H. Kanahashi, K. Higashi, Mater. Sci. Eng. A 28, 225 (2000)

[18] T. Mukai, H. Kanahashi, Y. Yamada, K. Shimojima, M. Mabuchi, T.G. Nieh, K. Higashi, Scr. Mater. 41, 365 (1999)

[19] P.F. Li, N.V. Nguyen, H. Hao, Mater. Des. 89, 636 (2016)

[20] H.J. Luo, L. Zhang, Z.G. Xu, Y.S. Yang, Mater. Sci. Forum 749, $356(2012)$

[21] T. Mukai, T. Miyoshi, S. Nakano, H. Somekawa, Scr. Mater. 54, $533(2006)$

[22] A. Aldoshan, S. Khanna, Mater. Sci. Eng. A 689, 17 (2017)

[23] P. Li, N. Petrinic, C.R. Siviour, R. Froud, J.M. Reed, Mater. Sci. Eng. A 515, 19 (2009)

[24] J.T. Fan, J. Weerheijm, L.J. Sluys, Mater. Des. 79, 73 (2015)

[25] W.Z. Huang, H.J. Luo, H. Lin, Y.L. Mu, B. Ye, J. Mater. Eng. Perform. 25, 1 (2016)

[26] Y.L. Mu, G.C. Yao, Z.K. Cao, H.J. Luo, G.Y. Zu, Scr. Mater. 64 $61(2011)$

[27] H. Asgari, J.A. Szpunar, A.G. Odeshi, Mater. Des. 61, 26 (2014)

[28] I.C. Choi, D.H. Lee, B. Ahn, K. Durst, M. Kawasaki, T.G. Langdon, J.I. Jang, Scr. Mater. 94, 44 (2015)

[29] W.Q. Song, P. Beggs, M. Easton, Mater. Des. 30, 642 (2009) 